\title{
Consumer Legal Protection against Distribution of PDAM Water in Central Java and the Problems
}

\author{
Sukarmi $^{1}$, Denny Suwondo ${ }^{2}$, Kami Hartono $^{3}$ \\ Faculty of Law, Universitas Islam Sultan Agung, Indonesia ${ }^{1,2,3}$ \\ \{sukarmi@unissula.ac/id ${ }^{1}$,denny@unissula.ac.id², hartono@unissula.ac.id ${ }^{3}$ \}
}

\begin{abstract}
The Legal Protection for PDAM Tirta Moedal Consumers has not optimally fulfilled justice, due to the reduced supply of available water discharge. The absence of coordination between leaders and employees as well as the absence of consumer education results in disharmony and unfair work. Fulfillment of obligations that is not accompanied by fulfillment of their rights has an impact on customer dissatisfaction, due to uneven distribution. This is due to reduced clean water discharge, decreased raw water sources, damaged channels due to lack of maintenance, so that water distribution is less than optimal. PDAM Tirta Moedal should always update information about related symptoms. The research aims to identify and analyze the causal factors and seek appropriate solutions to problems. The empirical juridical approach method is analyzed with the theory of legal protection and the theory of justice, it is proven that there are different legal bases. It is necessary to synchronize bases that can be understood by the parties and education on enlightenment in order to achieve social justice.
\end{abstract}

Keywords: Consumer Protection, Distribution, Social Justice

\section{Introduction}

Consumer protection is a situation where an "umbrella" is needed which provides and can be used to solve legal problems. Chairman of the Semarang Consumer Service and Protection Agency (LP2K) Ngargono said that in this situation his party encouraged PDAM Tirta Moedal and Semarang City Government to keep updating information on the condition of water discharge entering from Kudu, Kaligarang and springs. This information must be ensured to reach the customer in order to know clear information. Based on Article 1 point 1, consumer protection is all efforts to ensure legal certainty to provide protection to consumers.

This information is announced by taping or through printed media, which is clear that the public knows. PDAM Tirta Moedal believes that the information conveyed has been read by consumers, the facts are different. In addition to information on optimizing the mobility of tank use, it is also necessary to find water sources to other areas. This must be done in order to provide the best service to customers, so as not to sacrifice consumers whose payments are not differentiated whether the water supply is fulfilled or not. So that the consumer's right to 10 
cubic meters must be fulfilled in one month, otherwise there must be compensation given to the consumer. It is possible that the PDAM will move outside the area if the source of raw water has decreased.

Satjipto's legal protection theory: the present law aims to harmonize and coordinate interests so as not to collide with one another. Interests are coordinated by limiting and protecting those interests. Consumers according to their position still get legal protection, but limited legal protection is used, so that there are differences in their implementation, this can lead to something different as well. Rights not only contain elements of protection and interests, but also will.

Previous studies of consumers were disappointed because the distribution of water was often not smooth and cloudy, due to the fact that the waterways were often not smooth due to damaged channels in several places, due to lack of care and attention from the PDAM. This research also revolves around the lack of smooth water distribution, which is caused by a lack of clean water supply, and the PDAM is less creative in addressing the lack of water supply as its raw material. In addition, many concern that they do not understand based on the Consumer Protection Law (UUN Number 8 of 1999), while from PDAM Tirta Modal there are provisions of Government Regulations that must be considered, obeyed and implemented as a basis for work.

Efforts to improve services to the people of Semarang City in meeting the needs of clean water, achieving a healthy and prosperous community and increasing local revenue, require Regional Companies to manage drinking water that are wise, critical, intelligent and innovative and professional. Policies must be carried out in order to meet the needs of the general public fairly and obtain legal protection as expected by society

The incoming data is analyzed and solving problems regarding the obstacles that occur can be resolved optimally, so that the consumer community gets justice and legal protection. However, it should be noted that improving our point of view and changing mindsid or changing our minds is keeping a common commitment in order to improve conditions. The Consumer Protection Law must be addressed with self-awareness, introspection through mutual awareness education, trying to find the best solution according to various applicable government policies.

\section{Research Methods}

This study took several respondents as samples, interviewed and analyzed related officials with the theory of legal protection and the theory of Pancasila Justice. Digging in-depth information about what researchers want to know, with several resource persons with dialectical exchanges between researchers and informants continued to search for secondary data contained in literature studies through theoretical steps related to the 1945 Constitution of the Republic of Indonesia, provisions regarding policies. Regional government. Qualitative research specifications, namely legal research with several informants, aim to dig deeper into what researchers want to know by digging deeper into information from existing sources with dialectical exchanges between researchers and informants. This research was conducted in 2 (two) ways of collecting data, namely primary data and secondary data.

Unstructured and open interviews are intended to obtain spontaneous answers and a broader picture of the problem under study. This means an interview where the subject knows that they are being interviewed and knows the purpose and purpose of the interview. 
Informants who are research subjects to obtain primary data in conducting this research are analyzed with the theory of legal protection and justice.

The results found, there are different legal bases in the sense that the community does not know there are other steps used for the implementation of water distribution. It is necessary to inform about the synchronization of the basis for the public and the parties are known, educating the public so that there is no misunderstanding. Samples were taken randomly in the hope of getting a valid answer.

\section{Results and Discussion}

Regional Drinking Water Company (PDAM), a company trusted by the Government to manage "clean water" because it is a community need in daily life. The implementation of the responsibilities of these companies as public servants is often fraught with various problems related to consumer protection. In the implementation of these activities, consumers feel unfairly treated due to obstacles in its distribution to consumers. The fact that there is an unsynchronization between the regulations as a basis of foundation, has an impact on community annoyance. Whereas in fact this is not the case, this is more due to the failure of understanding by the consumer community, the PDAM explained but the consumer does not understand it. UUPK regulates consumer rights that are harmed by business actors, according to Article 19 UUPK business actors are responsible for providing compensation to consumers not only limited to money or goods, even health care and / or provision of compensation due to consuming contaminated drinking water. With regard to the PDAM's negligence towards consumers, PDAM has waived monthly subscription fees for the following month or according to customer requests. Meanwhile, PDAM is based on a Government Regulation which must also be considered because it has obligations that must be carried out in relation to Public Needs.

This obstacle is caused more by various things, both internal and external: Interns such as:

a) The basic material of water consists of wells as the main source;

b) Operational aids and their staples have not been managed effectively and in an orderly manner;

c) How to work, not being able to integrate into each employee, not having a sense of andarbeni (having ownership), not being able / feeling like a partner who can stick / unite, join andarbeni;

d) Infrastructure such as drains does not receive regular and periodic maintenance;

e) The level of supervision is less orderly;

f) There is no inherent supervision from the leadership to the employees, both administration employees and production employees;

g) There is no inherent supervision from PDAM on customers;

From an external perspective:

a) Legal basis: based on the legal norms of the UUNo Consumer Protection Act. 8 of 1999, hopes to become a scientific benchmark for the development of legal disciplines and public policy.

b) Semarang City Regional Regulation Number 8 of 2013 concerning Regional Drinking Water Company Tirto Moedal Semarang City and Regional Regulation Number 9 of 2016 concerning Amendment to Regional Regulation Number 8 of 2013 Daeerah Tirta Moedal 
Drinking Water Company in Semarang City explains that the goal of PDAM is to fulfill drinking water needs quality at affordable prices in order to support the realization of public health and as a source of Regional Original Income.

c) However, the facts that occur if these objectives have not been successfully carried out by PDAM Tirta Moedal Semarang City, because what is produced by the PDAM is not up to standard, namely that it can be consumed directly and at an increasingly skyrocketing price, is not balanced with improvements in water quality and quantity. in the Regional Regulation.

Based on article 6 and article 7 of the Semarang City Regional Regulation Number 8 of 2013, it is explained that the business scope of PDAM Tirta Moedal Semarang includes:

a) Production and distribution services for drinking water, and

b) Development of other businesses of the same type and not in contravention of the Prevailing Laws.

This needs to be reviewed:

a. This research was conducted using an empirical juridical approach, by examining the legal basis for implementing the implementation of laws and regulations, especially the UUPK and documents related to the protection of clean water consumers, and supported by interviews with clean water consumers and PDAM officials.

b. Policies undertaken, such as:

1. The government, the project-based drinking water infrastructure development budget approach, it is time for negotiations to be changed to a priority budget that prioritizes the fulfillment of basic rights of the community, adding bur wells as a source of basic materials for clean water.

2. PDAM to do:

a) routine and periodic equipment maintenance, distributing drinking water so that water contamination can be minimized;

b) replacement of equipment that is no longer feasible and carried out periodically;

c) However, if the equipment is damaged, it is urgent to prioritize it for good service to consumers;

3. Company leaders with employees:

a) Providing rewards as motivation for outstanding, critical, creative, innovative employees;

b) Solidarity and togetherness for better results;

c) Inspection to the administrative office (concerning management orderliness, administrative accuracy, neatness and discipline);

d) Briefing with office and production employees;

e) Critical dialogue with customers;

Often there are actions that are not as expected. The community at large, as consumers of goods and services, has rights and obligations in conducting transactions or agreements with business actors. Both individuals and business entities that are legal or not. This is stipulated in Law (UU) Number 8 of 1999 concerning Consumer Protection. Especially Article 4 related to consumer rights. Article 19 states as follows: paragraph (1) business actors are responsible for providing compensation for damage, pollution and / or loss to consumers due to consuming goods and / or services produced or traded. Followed by paragraph (2) which reads: "Compensation as referred to in paragraph 1 can be in the form of refunds or replacement of goods and / or services of similar value or equivalent in value, or health care 
and / or provision of compensation in accordance with the provisions of laws and regulations applicable."

Coordination and synchronization of the steps for implementing Government policies which form the basis of the PDAM must always be done as a basis for work. During this time, PDAM has distributed clean water, often there is an out of sync between the regulations used and their implementation, resulting in consumer annoyance, when in fact it is not like that. UUPK regulates consumer rights that are harmed by business actors, according to Article 19 UUPK business actors are responsible for providing compensation to consumers not only limited to money or goods, even health care and / or provision of compensation due to consuming contaminated drinking water. With regard to the PDAM's negligence towards consumers, PDAM has waived monthly subscription fees for the following month or according to customer requests

PDAM Moedal consumer protection even though it still does not fulfill justice, but along with the continuous education providing understanding, either through direct announcements, pasted on or via cell phone is done in order to provide understanding to consumers, as well as good coordination between leaders and employees and customer education /consumer.

Consumers feel treated unfairly on their rights as consumers, because:

a) Has not received valid information from the company;

b) Feeling that they have fulfilled their obligations but not accompanied by fulfilling their rights;

c) Lack of understanding of the correct water distribution procedures;

d) Lack of understanding where water sources are distributed or obtained from which sources;

e) The unequal distribution of PDAM in several areas has an impact on hindering daily activities, more due to reduced clean water discharge in some places, raw water sources have decreased due to damaged channels due to lack of maintenance, so that water distribution by PDAM Tirta Moedal is not optimal .

Based on the researcher's observations, the implementation of the responsibility carried out by PDAM Central Java Province (especially Semarang) is an effort to fulfill the responsibilities of business actors by settling customer claims and taking measures that may occur that may make it difficult for consumers in terms of clean water services in the future. which will come. This is in accordance with the provisions contained in the Law. No. 8 of 1999 concerning Consumer Protection

Regarding the decline in raw water sources, as long as this condition is well and continuously informed, consumers will want to understand and can be good at it. Unless consumers are critical, reading in print and electronic media, they can understand these conditions, understand the conditions. The problem is that there are still repeated leaks and not immediately repaired. Policies issued by the Government, such as, PDAMs do not need to pay dividends to the government, provided that the funds are diverted to repair leaking channels. If possible deposit in the form of notes, for example by showing notes for channel improvements etc. Previous research was conducted in 2015 from the results of the study, it was acknowledged that there were some obstacles to negligence from officers who paid less attention to complaints from the public, and less control from the leadership over the performance of field officers. Even in 2017, a study was conducted that found the reasons for the delay in distribution were more due to limited water discharge due to the dry season, so that the PDAM made efforts with a scheduling system, making a turn to distribute water to customers. On the other hand, consumers do not understand clean water supply, lack public 
awareness of the effectiveness of water distribution or distribution arrangements, do not understand the capacity of water supply / raw materials.

Failure to understand what consumers experience in receiving information, it is not always the fault of consumers, it is possible for the PDAM to misinform consumers. Article 19 UUPK business actors are responsible for providing compensation to consumers not only limited to money or goods, even health care and / or provision of compensation for consuming contaminated drinking water. With regard to the PDAM's negligence towards consumers, PDAM has waived monthly subscription fees for the following month or according to customer requests.

The next policy, To the Government, the project-based and negotiated water infrastructure development budget approach needs to be changed into a priority budget that prioritizes the fulfillment of basic rights of the community. For the maintenance needs of PDAM drinking water distribution equipment, so that water pollution can be minimized, it is even possible to replace equipment that is no longer suitable for good consumer service

Often there are actions that are not as expected. The community at large, as consumers of goods and services, has rights and obligations in conducting transactions or agreements with business actors. Both individuals and business entities that are legal or not. This is stipulated in Law (UU) Number 8 of 1999 concerning Consumer Protection. In particular, Article 4 is related to consumer rights, which amount to 9 items.

Article 19 states as follows: paragraph (1) business actors are responsible for providing compensation for damage, pollution and / or loss to consumers due to consuming goods and / or services produced or traded. Followed by paragraph (2) which reads: "Compensation as referred to in paragraph 1 can be in the form of refunds or replacement of goods and / or services of a similar or equivalent value, or health care and / or provision of compensation in accordance with the provisions of laws and regulations applicable." In this case the PDAM Chairman or Directors must have a firm attitude in accordance with applicable regulations.

\section{Conclusions}

a) Consumer legal protection for water distribution PDAM feels that it has not fulfilled the sense of social justice when viewed from the perspective of consumer understanding. However, from the point of view of the Business Actor / PDAM, this has carried out its obligations and rights according to Government regulations, but because the debit of clean water supply has indeed decreased, policies are taken and water distribution is carried out in rotation to fulfill justice.

b) Because there is a difference in understanding caused by the lack of understanding of consumers, education is carried out in order to understand and understand the Government policies that must be applied to PDAM Tirta Moedal because this is related to other policies that are intended to improve the welfare of the community related to the distribution of Clean Water from PDAM Tirta Moedal.

Advice and policies:

Company leaders and employees / PDAMs are expected to be more alert and critical, educative, innovative to always pay attention and be wise:

a) Leaders and employees are expected to have more self-awareness which must be cultivated into the souls of the Leaders and employees, as well as paying attention to and criticizing the company's facilities and infrastructure. 
b) Perform maintenance, repair of installations and water sources as raw material;

c) Reward employees who are diligent, critical, creative and innovative;

d) Fostering cohesiveness and togetherness;

e) Occasionally conduct inspection to administrative offices or production employees (concerning order, critical, work with dedication, discipline, a sense of belonging and wanting to always give the best to customers and offices).

f) Briefing or conducting critical dialogue with employees and customers to get feedback.

\section{References}

[1] The 1945 Constitution of the Republic of Indonesia (UUDNRI 1945),

[2] Law (UU) Number 8 Year 1999 regarding Consumer Protection

[3] Regional Regulation of the City of Semarang Number 8 Year 20013 concerning Regional Drinking Water Company Tirta Moedal Semarang City Article 5.

[4] Lili Rasjidi and B. Arief Sidharta, Madzab and Reflection Philosophy of Law (Bandung: PT. Remaja, Rosda Karya, 1994), 64. digilib.uinsby.ac.id

[5] Setiono, Rule of Law (Supremacy of Law), 2004, Thesis of Master of Law Science, Postgraduate Program of Sebelas Maret University, Surakarta, 3.

[6] Philipus M. Hadjon, 1987, Legal Protection for the Indonesian People, Surabaya: PT. Science Development.

[7] Muhammad and Alimin, Ethics and Consumer Protection in Islamic Economics, Jogyakarta, BPFE, 2004.

[8] MiruAhmadi and Sutarman Yodo, Consumer Protection Law, Yogyakarta, Raja Grafindo Persada

[9] https://www.google.com/search?client=firefox-b-d\&q=teori+keadilan+sos

[10] https://www.google.com/search?client=firefox-b-d\&q=teori+keadilan+sos

[11] https://panmohamadfaiz.com/2009/04/28/profil-tokoh-john-rawls-

[12] https://panmohamadfaiz.com/2009/04/28/profil-tokoh-john-rawls-

[13] digilib.uinsby.ac.id digilib.uinsby.ac.id digilib.uinsby.ac.id digilib.uinsby.ac.id 